dr hab. Wanda A. Ciszewska

Uniwersytet Mikołaja Kopernika w Toruniu

Instytut Informacji Naukowej i Bibliologii

tai@umk.pl

\title{
WYPŁATA WYNAGRODZENIA Z TYTUŁU PUBLIC LENDING RIGHT
}

\author{
The payment related to the Public Lending Right
}

\begin{abstract}
Abstrakt
Z końcem 2015 r. wprowadzono w Polsce public lending right - prawo publicznego użyczenia. Jest to jedno z praw autorskich, które daje ich właścicielowi możliwość decydowania o dopuszczeniu do wypożyczania dzieła, ale również prawo otrzymywania z tego tytułu wynagrodzenia. Instytucją wyznaczoną przez Ministra Kultury i Dziedzictwa Narodowego do dokonywania w latach 2016-2020 podziału i wypłaty wynagrodzenia za użyczanie przez biblioteki publiczne egzemplarzy utworów jest Stowarzyszenie Autorów i Wydawców Copyright Polska. Doszło już do pierwszych wypłat z tytułu PLR. Jest to zatem dobry czas, aby przyjrzeć się dokładniej jak ten system jest realizowany.
\end{abstract}

Słowa kluczowe: prawo autorskie, Stowarzyszenie Autorów i Wydawców Copyright Polska, wynagrodzenia za wypożyczenia biblioteczne.

\begin{abstract}
In 2015, public lending right was introduced in Poland. This is one of the copyright laws that gives the owner the power not only to decide about lending his work in the library, but also to receive remuneration for this. The Minister of Culture and National Heritage designated the Association of Authors and Publishers Copyright Polska to distribute and pay the fees for Public Lending Right in the 2016-2020 period. The first PLR payout has already taken the place, so it is a good time to take a closer look at how exactly this system works.
\end{abstract}


Keywords: copyright, Public Lending Right, Stowarzyszenie Autorów i Wydawców Copyright Polska, the Association of Authors and Publishers Copyright Polska.

\section{Użyczanie utworów przez biblioteki a prawo autorskie}

Biblioteki upowszechniają utwory, które za zgodą twórcy zostały $\mathrm{w}$ dowolny sposób udostępnione publicznie na podstawie Ustawy $z$ dnia 4 lutego 1994 r. o prawie autorskim i prawach pokrewnych ${ }^{1}$. W oparciu o punkt 1 art. 28 Ustawy biblioteki, muzea oraz archiwa mogą „użyczać, w zakresie swoich zadań statutowych, egzemplarze utworów rozpowszechnianych”. Jest to tzw. „przywilej biblioteczny”, czyli jedno z ograniczeń uprawnionego podmiotu $\mathrm{z}$ tytułu autorskich praw majątkowych, określanych ogólnie jako dozwolony użytek chronionych utworów ${ }^{2}$.

Bezpośrednio z udostępnianiem utworów przez biblioteki wiąże się pojęcie „Public Lending Right” (PLR), określane jako prawo publicznego użyczenia lub prawo do wynagrodzenia za użyczenia biblioteczne. Ta zmienność nazw wynika $\mathrm{z}$ rozważania tego terminu w dwóch ujęciach. W węższym zakresie PLR rozpatrywane jest jako jedno z praw autorskich przyznawanych właścicielowi praw (niekoniecznie twórcy) i wiąże się zapewnieniem mu prawa do autoryzowania lub zakazywania wypożyczeń dzieła wprowadzonego do obrotu publicznego. Drugi aspekt ujmuje PLR jako prawo do wynagrodzenia, które jest prawem twórcy i właścicieli praw autorskich do otrzymywania zadośćuczynienia finansowego z tytułu darmowego wypożyczania egzemplarzy ich utworów przez instytucje użyteczności publicznej $j^{3}$.

Początki PLR sięgają XIX w. Wielu autorów uznało wówczas rozwój bibliotekarstwa publicznego i powszechną dostępność wydawnictw za potencjalne zagrożenie dla poziomu swoich przychodów ze sprzedaży

1 Ustawa $z$ dnia 4 lutego 1994 r. o prawie autorskim i prawach pokrewnych. Dz.U. 1994, nr 24, poz. 83 - wersja ujednolicona Dz.U. 2017, poz. 880.

2 Ograniczenie to ma na celu zachowanie równowagi pomiędzy monopolem autorskim a szeroko pojętym interesem publicznym i wynika $\mathrm{z}$ troski o potrzeby informacyjne, naukowe i kulturalno-oświatowe społeczeństwa oraz swobodny dostęp do twórczości. W polskim prawie dozwolony użytek chronionych utworów określony jest w art. 23-35 Ustawy z dnia 4 lutego 1994 r., dz. cyt.

3 Materialy dodatkowe $w$ sprawie public lending right. Tłum. A. Lenarczyk, Weryfikacja B. Szczepańska. IFLA Committee on Copyright and Other Legal Matters. Kwiecień 2005. Tryb dostępu: http://www.ifla.org/files/assets/clm/position_papers/ifla-position-on-public-lending-right-2005_background-pl.pdf [12 czerwca 2017]. 
książek. W konsekwencji Generalne Stowarzyszenie Pisarzy Niemieckich w Darmstadt przyjęło w 1883 r. rezolucję, w której domagało się ustanowienia dla autorów dodatkowego wynagrodzenia za wypożyczanie ich książek przez biblioteki. Analogiczne przekonania wyraziła duńska pisarka Thit Jansen podczas dorocznej konferencji Stowarzyszenia Bibliotekarzy Duńskich w 1917 r. W efekcie to właśnie w Danii - po wieloletniej dyskusji o tym, czy bezpłatne wypożyczanie w bibliotece szkodzi, czy sprzyja interesom autorów - w 1946 r. wprowadzono pierwsze na świecie uregulowania prawne dotyczące systemu PLR ${ }^{4}$.

Obecnie prawo publicznego użyczenia do swojego ustawodawstwa wprowadziły 53 państwa, m.in.: większość państw członkowskich Unii Europejskiej, Kanada, Izrael, Australia, Nowa Zelandia. Jednak system wypłat $\mathrm{z}$ tego tytułu funkcjonuje tylko w 33 państwach, a $29 \mathrm{z}$ nich, w tym Polska, realizuje wypłaty $\mathrm{z}$ tego tytułu ${ }^{5}$.

Szczegółowych informacji o funkcjonowaniu sytemu PLR na świecie dostarcza dedykowana temu zagadnieniu strona internetowa dostępna pod adresem: https://www.plrinternational.com/. Popularyzuje ona wiadomości o prawie publicznego użyczenia obowiązującym w poszczególnych państwach, uwzględniając takie elementy, jak podstawa prawna, źródło finansowania, sposoby obliczania należności finansowych czy podmioty uprawnione do otrzymania wynagrodzenia $z$ tytułu PLR. Informacje zamieszczane na stronie są nadzorowane przez dra Jima Parkera, który był wcześniej dyrektorem instytucji zajmującej się systemem PLR w Wielkiej Brytanii ${ }^{6}$.

Informacji o systemie PLR można również znaleźć na stronie organizacji International Authors Forum, reprezentującej autorów z całego świata. Organizacja ta przygotowała specjalny przewodnik Public Lending Right Introductory Guide w formacie PDF w trzech wersjach językowych(angielskiej, francuskiej, hiszpańskiej) do pobrania pod adresem: http://internationalauthors.org/public-lending-right-introductory-guide-launched $/^{7}$.

4 Tamże.

5 How many countries recognise PLR? PLR International. Tryb dostępu: https://www. plrinternational.com/faqs/faqs.htm\#recognise [12 czerwca 2017].

6 PLR International. Tryb dostępu: www.plrinternational.com [12 czerwca 2017].

7 Przewodnik składa się z trzech części, z których najważniejsza jest pierwsza, opisująca różne rodzaje systemów PLR istniejące na arenie międzynarodowej i ich podstawy prawne. Część druga wyjaśnia rolę autorów w rozwoju życia kulturalnego i edukacji oraz zwraca uwagę na PLR jako źródło zapewniające autorom środki utrzymania. Część trzecia natomiast odsyła do stron organizacji, takich jak: International Authors 
System PLR powszechnie obowiązuje na terenie Unii Europejskiej ze względu na Dyrektywę Rady 92/100/EWG z 19 listopada 1992 r. w sprawie prawa najmu i użyczenia oraz niektórych praw pokrewnych prawu autorskiemu w zakresie własności intelektualnej. Państwa członkowskie Unii Europejskiej zobowiązały się wdrożyć Dyrektywę do 1 lipca 1994 r., jednak większość nie wywiązała się z tego obowiązku w przewidzianym terminie. Część z nich starała się wyłączyć spod sytemu PLR jak największą liczbę instytucji, opierając się na przepisie Dyrektywy, który umożliwia wyłączenie pewnych kategorii instytucji z obowiązku stosowania PLR. W efekcie Komisja Europejska podjęła przeciwko nim kroki prawne, a w niektórych przypadkach skierowała nawet sprawę do Trybunału Sprawiedliwości Unii Europejskiej. Ze względu na fakt, że Dyrektywa była już kilkakrotnie nowelizowana w 2006 r. ogłoszono jej wersję ujednoliconą - Dyrektywa 2006/115/WE) . $^{9}$

Zgodnie z art. 1 ust. 1 oraz art. 3 ust. 1 Dyrektywy 2006/115/WE twórcom przysługuje wyłączne prawo zezwalania lub zakazywania najmu i użyczenia ich utworów. W zakresie publicznego użyczenia państwa członkowskie mogą ustanowić odstępstwa od tego wyłącznego prawa, pod warunkiem jednak, że wynagrodzenie za takie użyczenie otrzymają przynajmniej twórcy. Państwa członkowskie mogą również swobodnie ustalać wynagrodzenia, biorąc pod uwagę „swoje cele promocji kultury” (art. 6 ust. 1).

\section{Polskie rozwiązania prawne dotyczące PLR}

Polska długo zwlekała z implementacją Dyrektywy, uzasadniając to obowiązującym „przywilejem bibliotecznym”. Jednak pod naciskiem insty-

Forum (www.internationalauthors.org), European Writers' Council (www.europeanwriterscouncil.eu) oraz International Federation of Reprographic Rights Organisations (www.ifrro.org) po więcej informacji i wskazówek. Public Lending Right Introductory Guide available now. Tryb dostępu: http://internationalauthors.org/wp-content/uploads/IAF-International-PLR-Guide.pdf [12 czerwca 2017].

8 A. Kurowska: Problem implementacji dyrektywy 2006/115/WE w zakresie public lending right. „Zeszyty Naukowe Uniwersytetu Jagiellońskiego. Prace z Prawa Własności Intelektualnej” 2009, z. 105. Tryb dostępu: http://www.lex.pl/akt/-/akt/problem-implementacji-dyrektywy-2006115we-w-zakresie-public-lending-right [12 czerwca 2017].

9 Dyrektywa 2006/115/WE Parlamentu Europejskiego i Rady z dnia 12 grudnia 2006 r. w sprawie prawa najmu i użyczenia oraz niektórych praw pokrewnych prawu autorskiemu w zakresie własności intelektualnej (wersja ujednolicona), „Dziennik Urzędowy Unii Europejskiej" L 376/28, 27/12/2006. Tryb dostępu: http://eur-lex.europa.eu/legalcontent/PL/TXT/?uri=CELEX:32006L0115 [12 czerwca 2017]. 
tucji i organizacji reprezentujących środowisko twórców i wydawców, jak i w obawie przed zaskarżeniem do Trybunału Sprawiedliwości UE, w 2013 r. w ramach Trzeciego Forum Prawa Autorskiego przeprowadzono szeroko zakrojone konsultacje społeczne dotyczące wprowadzenia i zasad funkcjonowania PLR.

Swoje stanowiska przedstawiły wówczas największe organizacje i instytucje związane z kulturą i rynkiem książki (m.in. Centrum Cyfrowe, Koalicja Otwartej Edukacji czy Stowarzyszenie Autorów ZAiKS), jak i najważniejsze podmioty bezpośrednio zainteresowane wprowadzeniem wynagrodzenia za wypożyczenia biblioteczne, reprezentujące środowisko bibliotekarzy (Biblioteka Narodowa, Stowarzyszenie Bibliotekarzy Polskich, Stowarzyszenie EBIB) oraz branżę wydawniczo-księgarską (Polska Izba Książki oraz Stowarzyszenie Autorów i Wydawców „Polska Książka”, które w 2014 r. zmieniło nazwę na Stowarzyszenie Autorów i Wydawców Copyright Polska (SAiW Copyright Polska) ${ }^{10}$.

Wyniki konsultacji społecznych i branżowych na temat implementacji Dyrektywy posłużyły do dalszych prac legislacyjnych prowadzonych przez Ministra Kultury i Dziedzictwa Narodowego (MKiDN). Ostatecznie wynagrodzenie za wypożyczenia biblioteczne wprowadzono Ustawa z dnia 11 września 2015 r. o zmianie ustawy o prawie autorskim i prawach pokrewnych oraz ustawy o grach hazardowych (Dz.U. 2015, poz. 1639).

Najważniejsze zapisy dotyczące PLR zawarto w rozszerzonym art. 28 znowelizowanej Ustawy o prawie autorskim. W ust. 4 tego artykułu jednoznacznie stwierdzono, że wynagrodzeniem za użyczanie objęte będą tylko „utwory wyrażone słowem, powstałe lub opublikowane w języku polskim w formie drukowanej” użyczane przez biblioteki publiczne. Krąg beneficjentów wypłat $z$ tytułu PLR określono stosunkowo szeroko. Zgodnie $\mathrm{z}$ ust. 5 wynagrodzenie przysługuje:

„1. twórcy utworu wyrażonego słowem, powstałego i opublikowanego w języku polskim;

2. tłumaczowi na język polski utworu wyrażonego słowem, powstałego w języku obcym i opublikowanego w języku polskim;

3. współtwórcy utworu, o którym mowa w pkt 1, którego wkład jest utworem plastycznym lub fotograficznym;

10 W. A. Ciszewska: Przywilej biblioteczny a prawo do wynagrodzenia za wypożyczenia biblioteczne (public lending right). „Toruńskie Studia Bibliologiczne” 2014, nr 2(13), s. $136,144$. 
4. wydawcy utworu wyrażonego słowem i opublikowanego w języku polskim"11.

Dzięki tak sformułowanemu zapisowi system PLR ma przynieść korzyści nie tylko twórcom, ale też być wsparciem dla twórczości w języku narodowym, zgodnie z art. 6 ust. 1 Dyrektywy 2006/115/WE.

Wynagradzanie za użyczanie przysługuje jedynie za udostępnianie utworów na zewnątrz, poza teren bibliotek publicznych (art. 28 ust. 6 Ustawy). Wynika to faktu, że udostępnianie na terenie bibliotek, obejmujące księgozbiór podręczny oraz czasopisma zazwyczaj nie jest rejestrowane w systemach wypożyczeń i nie jest włączane do statystyk bibliotecznych. System PLR nie obejmuje także użyczania egzemplarzy przez Bibliotekę Narodową (art. 28 ust. 7 Ustawy), przypuszczalnie dlatego, że zbiory tej instytucji z zasady udostępniane są prezencyjnie.

Zasady określania i wypłaty wynagrodzenia za użyczanie egzemplarzy utworów przez biblioteki publiczne zostały zapisane w Ustawie o prawie autorskim $\mathrm{w}$ artykułach 351 do 354. Wynagrodzenie $\mathrm{z}$ tytułu PLR będzie wypłacane $z$ dofinansowania przekazywanego przez MKiDN, pochodzącego ze środków Funduszu Promocji Kultury (art. 351 ust. 1 Ustawy). Finansowanie systemu PLR ze środków budżetowych było zapowiadane przez MKiDN już na etapie konsultacji podczas Trzeciego Forum Prawa Autorskiego, więc decyzja ta nie była zaskoczeniem ${ }^{12}$. Dofinansowanie na wypłatę wynagrodzenia $\mathrm{z}$ tytułu PLR w danym roku kalendarzowym odpowiada 5\% wartości zakupów materiałów bibliotecznych dokonanych przez biblioteki publiczne w poprzednim roku kalendarzowym. Po potrąceniu kosztów organizacyjno-administracyjnych $75 \%$ tej kwoty będzie wypłacane twórcy utworu, tłumaczowi na język polski i współtwórcy utworu, a 25\% wydawcy (art. 351 ust. 7 Ustawy).

Wynagrodzenie za użyczanie przysługuje po złożeniu pisemnego oświadczenia o woli otrzymywania wynagrodzenia za użyczanie, złożonego do organizacji zajmującej się wypłatami (art. 352 ust. 1 Ustawy). Systemem wypłat zatem będą objęci tylko ci twórcy, którzy dopełnią określonych

11 Ustawa $z$ dnia 4 lutego 1994 r. o prawie autorskim i prawach pokrewnych, dz. cyt., art. 28 ust. 5. W funkcjonujących na świecie systemach PLR wydawcy nie odgrywają zbyt wielkiej roli.

12 Implementacja Dyrektywy 2006/115/WE w zakresie prawa do wynagrodzenia za wypożyczenia biblioteczne (public lending right). Prawo autorskie i medialne. Forum Prawa Autorskiego. Warszawa, 02 października 2013. Tryb dostępu: http://www. prawoautorskie.gov.pl/media/trzecie_forum/Implementacja_wynagrodzenia_z_tytulu_public_lending_right.pdf [14 czerwca 2017]. 
formalności prawnych. Maksymalne wynagrodzenie wypłacone jednej osobie może wynieść pięciokrotność przeciętnego miesięcznego wynagrodzenia $\mathrm{w}$ sektorze przedsiębiorstw. Wynagrodzenie nie zostanie wypłacone danemu twórcy, jeśli nie przekroczy jednej dwusetnej przeciętnego miesięcznego wynagrodzenia (art. 352 ust. 6-7 Ustawy).

Zgodnie ze znowelizowaną Ustawa o prawie autorskim wypłata wynagrodzenia będzie dokonywana przez organizację zbiorowego zarządzania prawami autorskimi wyznaczoną przez MKiDN w drodze konkursu na okres nie dłuższy niż pięć lat (art. 351 ust. 2 Ustawy). Organizacja ta ma prawo finansowania swoich działań (udokumentowane koszty określenia wysokości wynagrodzenia za użyczanie i jego wypłaty) ze środków MKiDN przeznaczonych na system PLR, jednak wydatki te nie mogą przekroczyć $10 \%$ kwoty dofinansowania w danym roku (art. 351 ust. 10 Ustawy).

W latach 2015-2024 maksymalny limit wydatków MKiDN wypłacanych za użyczanie przez biblioteki publiczne egzemplarzy utworów wynosi $37600000 \mathrm{zl}, \mathrm{z}$ tego:

- w 2015 r. - 0 zt;

- w 2016 r. $-3801000 \mathrm{zl}$;

- w 2017 r. $-3881000 \mathrm{zl}$;

- w 2018 r. - $3978000 \mathrm{zł}$;

- w 2019 r. $-4073000 \mathrm{zł}$;

- w 2020 r. $-4171000 \mathrm{zl}$;

- w 2021 r. - $4271000 \mathrm{zl}$;

- w 2022 r. $-4374000 \mathrm{zl}$;

- w 2023 r. - $4474000 \mathrm{zl}$;

- w 2024 r. $-4577000 \mathrm{zt}^{13}$.

Wysokość wynagrodzenia za użyczanie jest określana proporcjonalnie do liczby użyczeń egzemplarzy utworów w roku poprzednim (art. 352 ust. 4 Ustawy). Podstawę do obliczenia wysokości wynagrodzenia z tytułu PLR stanowią informacje dotyczące użyczeń egzemplarzy utworów w danym roku kalendarzowym, przekazywane przez wybrane biblioteki w terminie 3 miesięcy od zakończenia roku kalendarzowego (art. 353 ust. 1 Ustawy). Wykaz 60 bibliotek publicznych zobowiązanych do przekazywania informacji o wypożyczeniach opublikowało MKiDN w Rozporzadzeniu $z$ dnia 2 listopada 2015 r. $w$ sprawie procedury podziału $i$ wypłaty wynagrodzenia za użyczanie. Lista ta wzbudza kontrowersje, bowiem wśród

13 Ustawa z dnia 11 września 2015 r. o zmianie ustawy o prawie autorskim i prawach pokrewnych oraz ustawy o grach hazardowych. Dz.U. 2015, poz. 1639, art. 5. ust. 1. 
wyznaczonych bibliotek znalazły się m.in.: Miejska Biblioteka w Ciechocinku, w Hajnówce, w Braniewie, Książnica Pomorska w Szczecinie, Książnica Płocka im. W. Broniewskiego. Na liście jest dziesięć bibliotek z woj. mazowieckiego, ale brakuje placówek z woj. małopolskiego czy pomorskiego ${ }^{14}$.

\section{Organizacja odpowiedzialna za wypłaty $z$ tytułu PLR}

Zgodnie z art. 351 ust. 2 Ustawy o prawie autorskim organizację zbiorowego zarządzania uprawnioną do podziału i wypłaty wynagrodzenia z tytułu PLR wybiera MKiDN w drodze konkursu. Konkurs ten został ogłoszony w „Biuletynie Informacji Publicznej” 24 lutego 2016 r. ${ }^{15}$ Warunkiem uczestnictwa w konkursie było m.in.:

- przedstawienie koncepcji zarządzania środkami otrzymanymi z tytułu PLR, na którą powinny złożyć się zasady dotyczące podziału i wypłaty wynagrodzeń za użyczanie oraz opis sposobu zapewnienia terminowej realizacji wypłat;

- uzasadnienie wysokości kosztów podziału i wypłaty wynagrodzenia za użyczanie;

- $\quad$ opis systemu informatycznego służącego do podziału i kontroli wypłaty wynagrodzenia za użyczanie ${ }^{16}$.

Do konkursu przystąpiły dwie organizacje zbiorowego zarządzania prawami autorskimi: Stowarzyszenie Zbiorowego Zarządzania Prawami Autorskimi Twórców Dzieł Naukowych i Technicznych KOPIPOL oraz SAiW Copyright Polska. Wyniki konkursu zostały ogłoszone w „Biuletynie Informacji Publicznej” 9 maja 2016 r. Komisja konkursowa powołana przez MKiDN, po dokonaniu oceny obu ofert, najwyższą liczbę punktów (86 na 100 punktów) przyznała ofercie SAiW Copyright Polska. Tym samym ta organizacja będzie dokonywała podziału i wypłat twórcom i wydawcom wynagrodzenia za wypożyczanie publikacji przez biblioteki publiczne w latach 2016-202017.

14 Rozporzadzenie Ministra Kultury i Dziedzictwa Narodowego z dnia 2 listopada 2015 r. $w$ sprawie procedury podziału $i$ wypłaty wynagrodzenia za użyczanie oraz wyznaczenia $w$ drodze konkursu organizacji zbiorowego zarządzania uprawnionej do podziału i wypłaty tego wynagrodzenia. Dz.U. 2015, poz. 1924.

15 Ogłoszenie konkursu. MKiDN. Biuletyn Informacji Publicznej. Tryb dostępu: http://bip. mkidn.gov.pl/pages/posts/ogloszenie-konkursu-1678.php [8 czerwca 2017].

16 Tamże.

17 Ogłoszenie wyniku konkursu. MKiDN. Biuletyn Informacji Publicznej. Tryb dostępu: http://bip.mkidn.gov.pl/pages/posts/ogloszenie-wyniku-konkursu-1704.php [8 czerwca 2017]; Minister MKiDN wyznaczył SAiW Copyright Polska do dokonywania podzia- 
Zgodnie ze swoim statutem SAiW Copyright Polska jest organizacją zrzeszającą autorów, wydawców oraz osoby zawodowo związane $z$ rynkiem wydawniczym. Celem stowarzyszenia jest zbiorowe zarządzanie prawami autorskimi i ochrona praw autorskich do różnego typu utworów. Podstawą działalności SAiW Copyright Polska jest zezwolenie Ministra Kultury z dnia 10 marca $2003 \mathrm{r}^{18}$ Od tego też roku na podstawie Rozporzadzenia Ministra Kultury z dnia 2 czerwca 2003 r. w sprawie określenia kategorii urządzeń i nośników stużących do utrwalania utworów oraz opłat od tych urządzeń i nośników z tytulu ich sprzedaży przez producentów $i$ importerów (Dz.U. 2003, nr 105, poz. 991) oraz Rozporządzenia Ministra Kultury $z$ dnia 27 czerwca 2003 r. w sprawie opłat uiszczanych przez posiadaczy urzadzeń reprograficznych (Dz.U. 2003, nr 132, poz. 1232) stowarzyszenie jest odpowiedzialne za pobieranie opłat reprograficznych należnych wydawcom (50\% opłat reprograficznych) i redystrybucję tych środków pomiędzy to środowisko. Stowarzyszenie stworzyło efektywny mechanizm opłat reprograficznych obejmujący około 950-1100 wydawców, na których konto wpływa rocznie kwota około 4,5-5,5 mln $\mathrm{z}^{19}$.

SAiW Copyright Polska jako organizacja prowadząca inkaso opłat reprograficznych, już na etapie konsultacji dotyczących wprowadzenia PLR jednoznacznie wyraziła chęć prowadzenia systemu wypłat wynagrodzeń z tytułu użyczeń bibliotecznych, argumentując, że jej doświadczenie w tego typu działaniach pozwoli na zmniejszenie kosztów obsługi systemu ${ }^{20}$.

\section{Rejestracja na platformie wypłat z tytułu PLR}

SAiW Copyright Polska przygotowała specjalną platformę PLR Wynagrodzenia za wypożyczenia biblioteczne, dostępną pod adresem:

łu i wypłaty wynagrodzeń z tytułu Public Lending Right. Tryb dostępu: https://www. copyrightpolska.pl/pl/3/0/251/Wynagrodzenia-PLR [8 czerwca 2017].

18 Statut SAiW Copyright Polska. Tryb dostępu: http://www.copyrightpolska.pl/docs/statut.pdf [8 czerwca 2017]; Zezwolenie Ministra Kultury z dnia 10 marca 2003 r. SAiW Copyright Polska. Tryb dostępu: http://www.copyrightpolska.pl/docs/zezwolenie.pdf [8 czerwca 2017].

19 Stowarzyszenie Autorów i Wydawców Copyright Polska w ramach realizacji zbiorowego zarzadu prawami autorskimi prowadzi inkaso opłat reprograficznych. Tryb dostępu: https://www.copyrightpolska.pl/pl/3/44/23/Uprawnienia-inkasowe [8 czerwca 2017]; Co autorzy zyskaja jako członkowie w SAiW Copyright Polska dzięki rozszerzeniu zezwolenia SAiW CP obejmującego również twórców. Tryb dostępu: https://www.copyrightpolska.pl/pl/3/261/239/Zapraszamy-autorow [14 czerwca 2017].

20 W. A. Ciszewska, dz. cyt., s. 152-153. 
https://plr.copyrightpolska.com.pl/login. Twórcy i wydawcy, aby ubiegać się o wynagrodzenie z tytułu PLR, muszą dopełnić formalności prawnych i zarejestrować się w systemie.

\section{Rysunek 1. Strona główna portalu PLR - Wynagrodzenia za wypożyczenia biblioteczne}

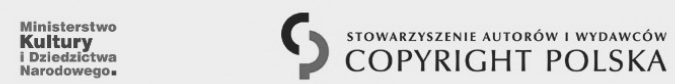

PLR - Wynagrodzenia za wypożyczenia biblioteczne

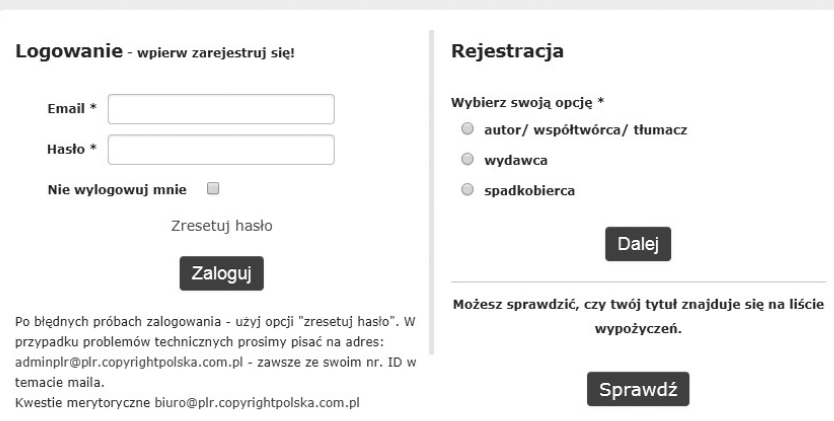

IEM NAM PRAW DO ZBIOROWEGO ZARZADZANIA SWOIMI UTWORAMI! ZAPRASZAMY DO

(e) Stowarzyszenie Autorów i Wydawców COPYRIGHT POLSKA

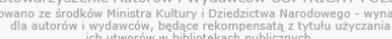

Źródło: PLR - Wynagrodzenia za wypożyczenia biblioteczne. SAiW Copyright Polska. Tryb dostępu: https://plr.copyrightpolska.com.pl/login [8 czerwca 2017].

Strona główna portalu umożliwia rejestrację w systemie PLR jako autor/współtwórca/tłumacz, wydawca lub spadkobierca praw autorskich. $\mathrm{Na}$ dzień 8 czerwca 2017 r. - o czym informuje ruchomy baner - 360 autorów zadeklarowało zainteresowanie członkostwem w SAiW Copyright Polska. Można przypuszczać zatem, że co najmniej tylu autorów zarejestrowało się już w systemie. Ponadto strona główna portalu daje także możliwość sprawdzenia, czy dany tytuł znajduje się na liście wypożyczeń ${ }^{21}$.

21 PLR - Wynagrodzenia za wypożyczenia biblioteczne. SAiW Copyright Polska. Tryb dostępu: https://plr.copyrightpolska.com.pl/login [8 czerwca 2017]. 


\section{Rysunek 2. Sprawdzanie tytułu na liście wypożyczeń}

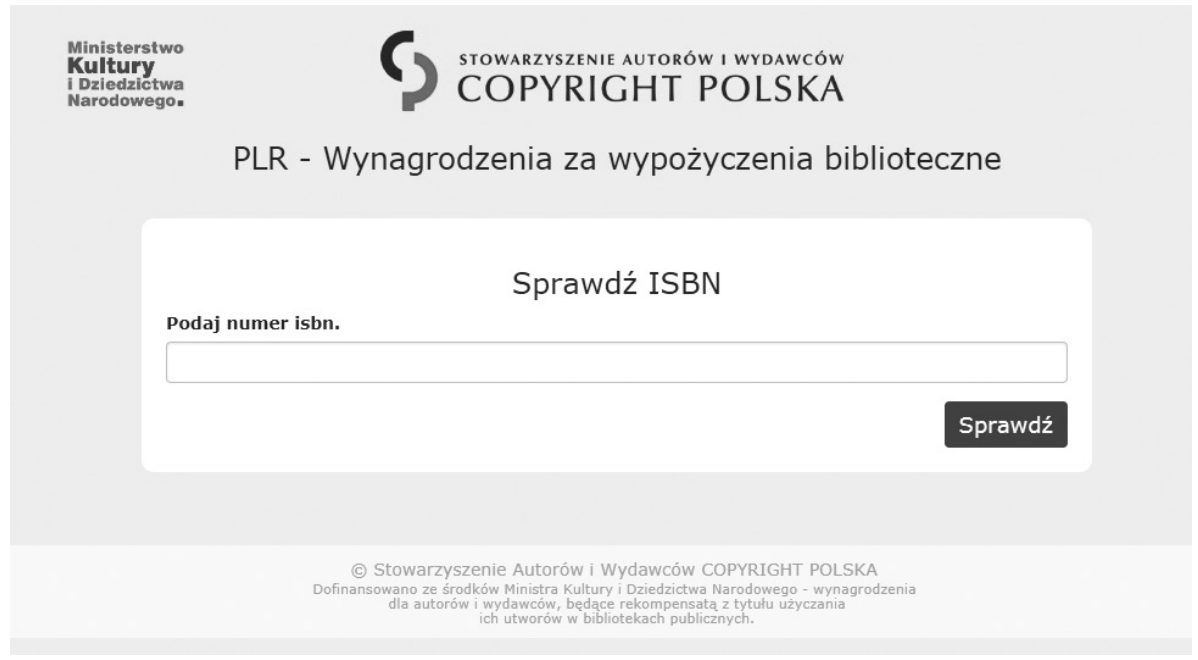

Źródło: Sprawdź ISBN. SAiW Copyright Polska. Tryb dostępu: https://plr.copyrightpolska.com.pl/sprawdz-isbn [8 czerwca 2017].

Proces rejestracji autora na platformie PLR jest stosunkowo prosty. Po wyborze na stronie głównej roli, w tym wypadku „autora” i przejściu dalej pokazuje się okno Rejestracja $w$ bazie wypożyczeń bibliotecznych. Należy wówczas podać adres email, hasło oraz zaakceptować regulamin. Po zarejestrowaniu wraca się do strony głównej, a na podany email zostaje wysłany link aktywacyjny, za pomocą którego należy potwierdzić rejestrację.

Po potwierdzeniu rejestracji należy zalogować się na platformie, aby dokończyć proces rejestracji i przejść do złożenia oświadczenia wymaganego przez system obsługujący wynagrodzenia za wypożyczenia biblioteczne. Następnie przechodzi się do kwestionariusza osobowego, gdzie należy podać szereg informacji - różnych w zależności od tego, czy rejestrujemy się jako autor, wydawca czy spadkobierca. Dla autora jest to m.in.: imię, nazwisko, pseudonim - jeśli się taki posiada, numer PESEL, dane adresowe oraz numer konta bankowego. Spadkobierca w pierwszej kolejności określa, po kim odziedziczył autorskie prawa majątkowe, podając następujące dane spadkodawcy: imię, nazwisko, pseudonim autora. Ponadto można także zadeklarować chęć pozostania członkiem SAiW Copyright Polska lub powierzenia Stowarzyszeniu zarządu swoich praw autorskich. 


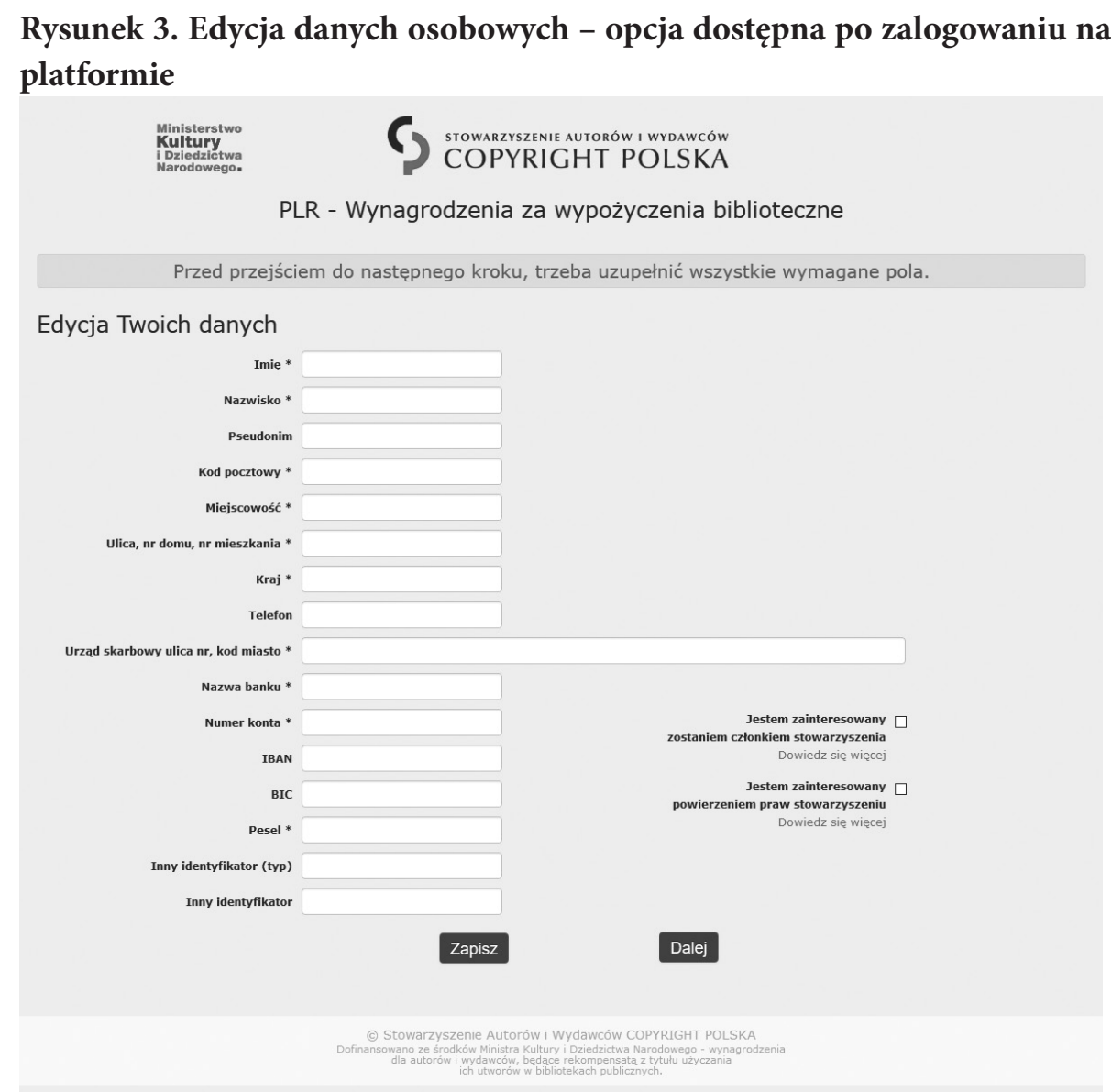

Źródło: PLR - Wynagrodzenia za wypożyczenia biblioteczne. SAiW Copyright Polska. Tryb dostępu: https://plr.copyrightpolska.com.pl/login [5 czerwca 2017].

W następnym kroku dodaje się utwory, które zostaną objęte oświadczeniem o woli otrzymania wynagrodzenia $\mathrm{z}$ tytułu użyczeń bibliotecznych. Niezbędne do tego są takie informacje jak: tytuł, ISBN, wydawca, rok wydania. Ważne jest, aby ISBN wpisać bez myślników jako ciąg cyfr. Wpisany z myślnikami nie zostanie „skojarzony” z danymi wypożyczeń. Po uzupełnieniu wszystkich wymaganych pól utwór zostaje dodany do platformy ${ }^{22}$.

Jeżeli utwór jest efektem pracy wielu twórców należy dodatkowo wskazać w oświadczeniu wielkość udziału uprawnionego składającego oświadczenie, ustaloną na podstawie umowy zawartej z wydawcą i w dalszych

22 Pytania i odpowiedzi - FAQ. SAiW Copyright Polska. Tryb dostępu: https://www.copyrightpolska.pl/pl/3/251/259/FAQ--pytania-i-odpowiedzi [5 czerwca 2017]. 
krokach załączyć kopię tej umowy. W przypadku spadkobierców należy także załączyć wersję elektroniczną dokumentów potwierdzających przejście autorskich praw majątkowych do utworu oraz dokumentów wskazujących udział w tym dziedziczeniu.

\section{Rysunek 4. Dodanie utworu - funkcja dostępna po zalogowaniu na platformie}

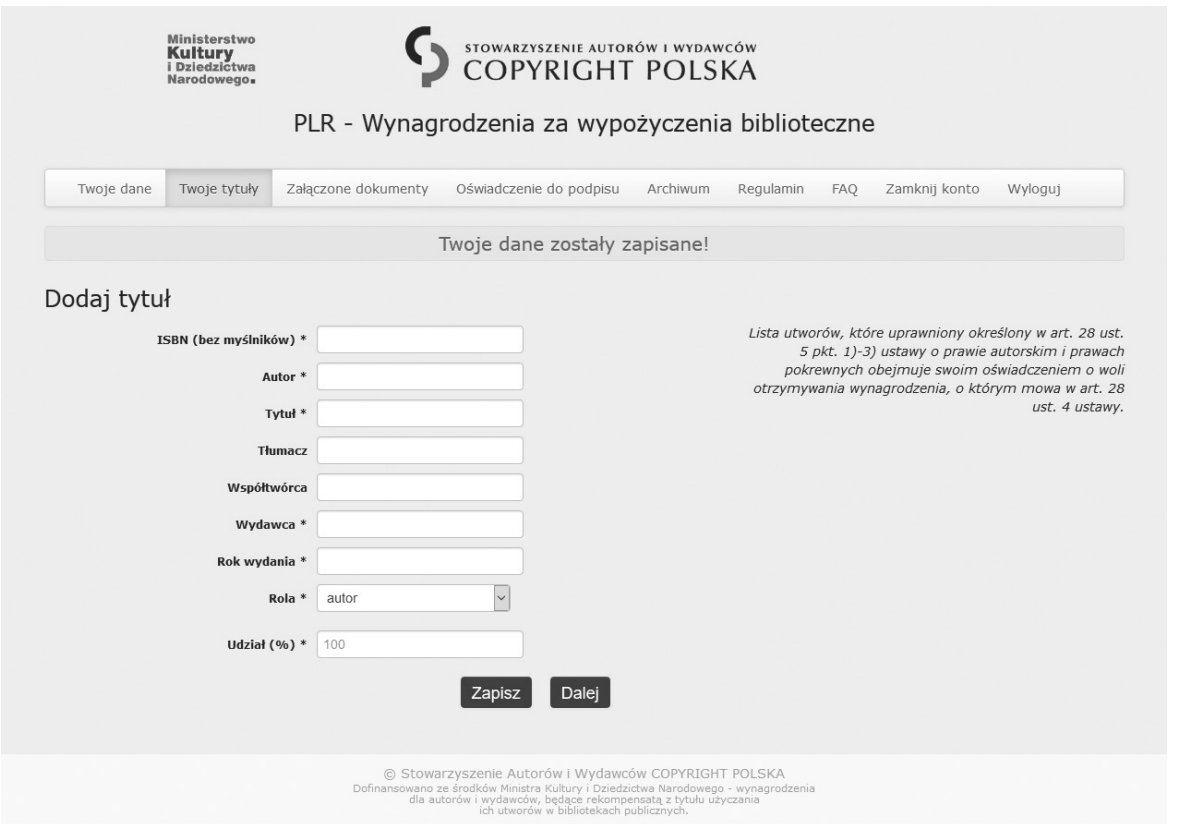

Źródło: PLR - Wynagrodzenia za wypożyczenia biblioteczne. SAiW Copyright Polska. Tryb dostępu: https://plr.copyrightpolska.com.pl/login [5 czerwca 2017].

Po wypełnieniu oświadczenia należy je wydrukować, podpisać i wysłać do SAiW Copyright Polska pocztą do 31 sierpnia danego roku. Przepisy prawa autorskiego nakładają na uprawnionych obowiązek przesłania oświadczeń $\mathrm{w}$ formie pisemnej, a sam portal PLR - Wynagrodzenia za wypożyczenia biblioteczne ma jedynie usprawnić przygotowanie oświadczenia ${ }^{23}$.

Zarówno założenie profilu, jak i uzupełnienie informacji oraz dodawanie kolejnych publikacji jest proste i intuicyjne. Dodatkowo dla osób niekorzystających z Internetu istnieje możliwość przesłania kompletnej dokumentacji przygotowanej tradycyjnie, jednak bezwzględnie wyma-

23 Tamże. 
gane jest dołączenie podpisanego oświadczenia, którego wzór w formacie PDF, jest do pobrania pod adresem: https://www.copyrightpolska.pl/docs/ zgoda_tworca.pdf ${ }^{24}$.

\section{Wypłaty wynagrodzenia z tytułu PLR}

Pierwsze wynagrodzenia za użyczenia biblioteczne w 2015 r. otrzymali ci twórcy oraz wydawcy, którzy zarejestrowali się w systemie PLR do 31 sierpnia 2016 r. Jak podało SAiW Copyright Polska, w tym terminie 1350 autorów, tłumaczy i współtwórców oraz 150 wydawców prawidłowo złożyło oświadczenia o woli otrzymywania wynagrodzenia za wypożyczenia biblioteczne. Po weryfikacji oświadczeń z danymi z bibliotek publicznych w grudniu 2016 r. wynagrodzenie otrzymało 1185 uprawnionych. Na podstawie wyliczeń SAiW Copyright Polska średnia wypłata to około 2 tys. zł. Najmniejsza kwota przeznaczona do wypłaty wyniosła $40 \mathrm{zł}$, natomiast największa to 21,4 tys. zł. Odpowiada to rocznemu maksymalnemu wynagrodzeniu z tytułu PLR, które ma być pięciokrotnością przeciętnego miesięcznego wynagrodzenia, czyli wynieść właśnie ponad 20 tys. $\mathrm{z}^{25}$. Wynagrodzenia za wypożyczenia biblioteczne w 2016 r. zostaną wypłacone pod koniec 2017 r. Osoby zainteresowane mogą złożyć swoje oświadczenia woli otrzymywania wynagrodzenia lub je zaktualizować o nowe publikacje do 31 sierpnia 2017 r. $^{26}$

\section{Podsumowanie}

Prawo do wynagrodzenia $\mathrm{z}$ tytułu PLR przysługuje nie tylko autorom tekstu i tłumaczom, ale także ilustratorom i fotografikom, jeśli byli oni, wraz z autorami tekstów, współtwórcami polskich publikacji. Siedemdziesiąt lat od śmierci autora po wynagrodzenie za dany utwór mogą się zgłaszać także jego spadkobiercy. Rejestracja na platformie 1,5 tys. twórców i wydawców

24 Informacja dla osób nie mających dostępu do Internetu. Tryb dostępu: https://www. copyrightpolska.pl/pl/3/251/253/Przed-rejestracja-w-PLR [14 czerwca 2017].

25 Wynagrodzenia dla autorów za wypożyczenia biblioteczne. Instytut Książki. Tryb dostępu: http://www.instytutksiazki.pl/wydarzenia,aktualnosci,36185,wynagrodzenia-dla -autorow-za-wypozyczenia-biblioteczne.html [14 czerwca 2017]; Autorzy ksiązek moga zgłaszać się po pieniądze za wypożyczenia biblioteczne. Gazeta Prawna.pl. Tryb dostępu: http://serwisy.gazetaprawna.pl/prawo-autorskie/artykuly/964291,autorzy-ksiazek-moga-zglaszac-sie-po-pieniadze-za-wypozyczenia-biblioteczne.html [14 czerwca 2017].

26 Tamże. 
to bardzo mało w stosunku do 32716 tytułów wydanych w $2014 \mathrm{r}$. i ponad 40500 podmiotów wydawniczych zarejestrowanych do połowy w $2014 \mathrm{r}$. w bazie ISBN, prowadzonej przez Bibliotekę Narodową ${ }^{27}$. Można zauważyć wyjątkowo niskie zainteresowanie twórców wynikające nie tylko z braku troski o swoje interesy ekonomiczne, ale również z powodu, a może przede wszystkim, braku wiedzy o uprawnieniach do wynagrodzeń z tytułu użyczeń bibliotecznych.

Krótki przewodnik po wynagrodzeniach za użyczenia biblioteczne przygotowało Stowarzyszenie Tłumaczy Literatury ${ }^{28}$, Związek Polskich Artystów Plastyków ma na swojej stronie zakładkę poświęconą prawu autorskiemu, brak tam jednak informacji o systemie PLR $^{29}$, który dotyczy przecież także ilustratorów. Środowiska autorów wydają się nie dostrzegać zmiany prawa autorskiego i wprowadzenia opłat za użyczenia biblioteczne. Na stronach Związku Literatów Polskich - organizacji twórczej i zawodowej pisarzy, jak i Stowarzyszenia Pisarzy Polskich, skupiającego prozaików, poetów, dramatopisarzy, krytyków literackich i tłumaczy brak jakichkolwiek informacji poświęconych temu zagadnieniu. Tym istotniejszą rolę odgrywa promocja informacji o systemie PLR w środowisku twórców.

\section{Bibliografia}

1. Autorzy książek moga zgłaszać się po pieniadze za wypożyczenia biblioteczne. Gazeta Prawna.pl. Tryb dostępu: http://serwisy.gazetaprawna.pl/prawo-autorskie/artykuly/964291,autorzy-ksiazek-moga-zglaszac-sie-po-pieniadze-za-wypozyczenia-biblioteczne.html [14 czerwca 2017].

2. Ciszewska W. A.: Przywilej biblioteczny a prawo do wynagrodzenia za wypożyczenia biblioteczne (public lending right). „Toruńskie Studia Bibliologiczne” 2014, nr 2(13), s. 135-159.

3. Co autorzy zyskaja jako członkowie w SAiW Copyright Polska dzięki rozszerzeniu zezwolenia SAiW CP obejmującego również twórców. Tryb dostępu:

27 Polska produkcja książek w roku 2014 - tytuły. „Ruch Wydawniczy w Liczbach” R. 60 (2014). Tryb dostępu: http://ksiegarnia.bn.org.pl/pdf/RWwL.pdf [14 czerwca 2017]; P. Dobrołęcki: Rynek książki w Polsce 2015. Tryb dostępu: http://www.instytutksiazki. pl/upload/Files/polish_book_market_2015_PL_popr.pdf [14 czerwca 2017].

28 Wynagrodzenia od wypożyczeń bibliotecznych. Stowarzyszenie Tłumaczy Literatury. Tryb dostępu: http://stl.org.pl/baza-wiedzy/sytuacja-tlumacza/wynagrodzenia-od-wypozyczen-bibliotecznych/ [14 czerwca 2017].

29 Prawa autorskie - OZZ. Związek Polskich Artystów Plastyków. Tryb dostępu: http://zpap. $\mathrm{pl} /$ zpap/index.php?option=com_content\&view=section\&id=10\&Itemid=216\&lang=pl [14 czerwca 2017]. 
https://www.copyrightpolska.pl/pl/3/261/239/Zapraszamy-autorow [14 czerwca 2017].

4. Dobrołęcki P.: Rynek książki w Polsce 2015. Tryb dostępu: http://www.instytutksiazki.pl/upload/Files/polish_book_market_2015_PL_popr.pdf [14 czerwca 2017].

5. Dyrektywa 2006/115/WE Parlamentu Europejskiego i Rady z dnia 12 grudnia 2006 r. w sprawie prawa najmu i użyczenia oraz niektórych praw pokrewnych prawu autorskiemu w zakresie własności intelektualnej (wersja ujednolicona). „Dziennik Urzędowy Unii Europejskiej” L 376/28, 27/12/2006. Tryb dostępu: http://eur-lex.europa.eu/legal-content/PL/TXT/?uri=CELEX:32006L0115 [12 czerwca 2017].

6. How many countries recognise PLR? PLR International. Tryb dostępu: https https://www.plrinternational.com/faqs/faqs.htm\#recognise [12 czerwca 2017].

7. Implementacja Dyrektywy 2006/115/WE w zakresie prawa do wynagrodzenia za wypożyczenia biblioteczne (public lending right). Prawo autorskie i medialne. Forum Prawa Autorskiego. Warszawa, 02 października 2013. Tryb dostępu: http://www.prawoautorskie.gov.pl/media/trzecie_forum/Implementacja_wynagrodzenia_z_tytulu_public_lending_right.pdf [14 czerwca 2017].

8. Informacja dla osób nie majacych dostępu do Internetu. Tryb dostępu: htps://www.copyrightpolska.pl/pl/3/251/253/Przed-rejestracja-w-PLR [14 czerwca 2017].

9. Kurowska A.: Problem implementacji dyrektywy 2006/115/WE w zakresie public lending right. „Zeszyty Naukowe Uniwersytetu Jagiellońskiego. Prace z Prawa Własności Intelektualnej” 2009, z. 105. Tryb dostępu: http://www.lex. $\mathrm{pl} /$ akt/-/akt/problem-implementacji-dyrektywy-2006115we-w-zakresie-public -lending-right [12 czerwca 2017].

10. Materiały dodatkowe $w$ sprawie public lending right. Tłum. A. Lenarczyk, W. B. Szczepańska. IFLA Committee on Copyright and Other Legal Matters. Kwiecień 2005. Tryb dostępu: http://www.ifla.org/files/assets/clm/position_papers/ifla-position-on-public-lending-right-2005_background-pl.pdf [12 czerwca 2017].

11. Minister MKiDN wyznaczył SAiW Copyright Polska do dokonywania podziału i wypłaty wynagrodzeń $z$ tytułu Public Lending Right. Tryb dostępu: https:// www.copyrightpolska.pl/pl/3/0/251/Wynagrodzenia-PLR [8 czerwca 2017].

12. Ogłoszenie konkursu. Biuletyn Informacji Publicznej MKiDN. Tryb dostępu: http://bip.mkidn.gov.pl/pages/posts/ogloszenie-konkursu-1678.php [8 czerwca 2017].

13. Ogłoszenie wyniku konkursu. Biuletyn Informacji Publicznej MKiDN. Tryb dostępu: http://bip.mkidn.gov.pl/pages/posts/ogloszenie-wyniku-konkursu-1704. php [8 czerwca 2017].

14. PLR - Wynagrodzenia za wypożyczenia biblioteczne. SAiW Copyright Polska. Tryb dostępu: https://plr.copyrightpolska.com.pl/login [8 czerwca 2017].

15. PLR international. Tryb dostępu: www.plrinternational.com [12 czerwca 2017].

16. Polska produkcja książek $w$ roku 2014 - tytuły. „Ruch Wydawniczy w Liczbach” R. 60 (2014). Tryb dostępu: http://ksiegarnia.bn.org.pl/pdf/RWwL.pdf [14 czerwca 2017]. 
17. Prawa autorskie - OZZ. Związek Polskich Artystów Plastyków. Tryb dostępu: http://zpap.pl/zpap/index.php?option=com_content\&view=section\&id=10\&Itemid=216\&lang=pl [14 czerwca 2017].

18. Public Lending Right Introductory Guide available now. Tryb dostępu: http:// internationalauthors.org/wp-content/uploads/IAF-International-PLR-Guide. pdf [12 czerwca 2017].

19. Pytania i odpowiedzi - FAQ. SAiW Copyright Polska. Tryb dostępu: https://www.copyrightpolska.pl/pl/3/251/259/FAQ--pytania-i-odpowiedzi [5 czerwca 2017].

20. Rozporządzenie Ministra Kultury i Dziedzictwa Narodowego z dnia 2 listopada 2015 r. w sprawie procedury podziału $i$ wypłaty wynagrodzenia za użyczanie oraz wyznaczenia $w$ drodze konkursu organizacji zbiorowego zarzadzania uprawnionej do podziału i wypłaty tego wynagrodzenia. Dz.U. 2015, poz. 1924.

21. Statut SAiW Copyright Polska. Tryb dostępu: http://www.copyrightpolska.pl/ docs/statut.pdf [8 czerwca 2017].

22. Stowarzyszenie Autorów i Wydawców Copyright Polska w ramach realizacji zbiorowego zarzadu prawami autorskimi prowadzi inkaso oplat reprograficznych. Tryb dostępu: https://www.copyrightpolska.pl/pl/3/44/23/Uprawnienia -inkasowe [8 czerwca 2017].

23. Ustawa $z$ dnia 11 września 2015 r. o zmianie ustawy o prawie autorskim i prawach pokrewnych oraz ustawy o grach hazardowych. Dz.U. 2015, poz. 1639, art. 5. ust. 1.

24. Ustawa z dnia 4 lutego 1994 r. o prawie autorskim i prawach pokrewnych. Dz.U. 1994, nr 24, poz. 83. - wersja ujednolicona Dz.U. 2017, poz. 880.

25. Wynagrodzenia dla autorów za wypożyczenia biblioteczne. Instytut Książki. Tryb dostępu: http://www.instytutksiazki.pl/wydarzenia,aktualnosci, 36185, wynagrodzenia-dla-autorow-za-wypozyczenia-biblioteczne.html [14 czerwca 2017].

26. Wynagrodzenia od wypożyczeń bibliotecznych. Stowarzyszenie Tłumaczy Literatury. Tryb dostępu: http://stl.org.pl/baza-wiedzy/sytuacja-tlumacza/wynagrodzenia-od-wypozyczen-bibliotecznych/ [14 czerwca 2017].

27. Zezwolenie Ministra Kultury $z$ dnia 10 marca 2003 r. SAiW Copyright Polska. Tryb dostępu: http://www.copyrightpolska.pl/docs/zezwolenie.pdf [8 czerwca 2017]. 